\title{
Improved transduction efficiency of a lentiviral vector for neuron-specific retrograde gene transfer by optimizing the junction of \\ fusion envelope glycoprotein
}

Shigeki Kato ${ }^{\text {a }}$, Kenta Kobayashi ${ }^{\text {b }}$, Kazuto Kobayashi ${ }^{\text {a,c }}$

${ }^{a}$ Department of Molecular Genetics, Institute of Biomedical Sciences, Fukushima

Medical University School of Medicine, Fukushima 960-1295, Japan

${ }^{\mathrm{b}}$ Section of Viral Vector Development, National Institute of Physiological Sciences, Okazaki 444-8585, Japan

${ }^{\mathrm{c}}$ Core Research for Evolutional Science and Technology, Japan Science and Technology Agency, Kawaguchi 332-0012, Japan

Corresponding author: Kazuto Kobayashi, Ph.D.

Department of Molecular Genetics, Institute of Biomedical Sciences,

Fukushima Medical University School of Medicine, Fukushima 960-1295, Japan

Tel: +81-24-547-1667; Fax: +81-24-548-3936; E-mail: kazuto@fmu.ac.jp 


\section{ABSTRACT}

\section{Background}

The vector for neuron-specific retrograde gene transfer (NeuRet) is a pseudotype of human immunodeficiency virus type 1 (HIV-1)-based vector with fusion glycoprotein type $\mathrm{C}(\mathrm{FuG}-\mathrm{C})$, which consists of the $\mathrm{N}$-terminal region of the extracellular domain of rabies virus glycoprotein (RVG) and the membrane-proximal region of the extracellular domain and the transmembrane/cytoplasmic domains of vesicular stomatitis virus glycoprotein (VSVG). The NeuRet vector shows a high efficiency of gene transfer through retrograde axonal transport and transduces selectively neuronal cells around the injection site.

\section{New Method}

We aimed to improve the efficiency of retrograde gene transfer of the NeuRet vector by optimizing the junction of RVG and VSVG segments in fusion glycoproteins in their membrane-proximal region.

\section{Results}

We produced various types of fusion glycoproteins, in which the junction of the two 
glycoprotein segments diverged in the membrane-proximal region and used for pseudotyping of HIV-1-based vector to evaluate the in vivo gene transfer efficiency after intrastriatal injection. We found a novel type of fusion glycoprotein termed type $\mathrm{E}$ (FuG-E) that yielded enhanced efficiency of retrograde gene delivery, showing neuron-specific transduction surrounding the injection site.

\section{Comparison with Existing Methods}

The NeuRet vector pseudotyped with FuG-E displayed the improved efficiency of retrograde gene transfer into different neural pathways compared with the original vector pseudotyped with FuG-C.

\section{Conclusions}

Our vector system with FuG-E provides a powerful tool for gene therapeutic trials of neurological and neurodegenerative diseases and for the study of the mechanisms of neural networks underlying various brain functions.

Keywords: Lentiviral vector; Retrograde gene transfer; Fusion glycoprotein; Neuron;

Gene Therapy; Neural circuit. 
Abbreviations: FuG-B, fusion glycoprotein type B; FuG-C, fusion glycoprotein type C;

FuG-E, fusion glycoprotein type E; GFAP, glial fibrillary acidic protein; GFP, green

fluorescent protein; HiRet, highly efficient retrograde gene transfer; HIV-1, human

immunodeficiency virus type 1; IL-2R $\alpha$, interleukin-2 receptor $\alpha$-subunit; M1, primary

motor cortex; NeuRet, neuron-specific retrograde gene transfer; PBS,

phosphate-buffered saline; PF, parafascicular nucleus; PV, Pasteur virus; RVG, rabies

virus glycoprotein; S1, primary somatosensory cortex; VSVG, vesicular stomatitis virus glycoprotein. 


\section{Introduction}

Viral vectors for gene transfer through retrograde axonal transport mediate the delivery of transgenes into neuronal cell bodies that innervate the region around the injection site of the vectors. These vectors provide a powerful approach for gene therapy of neurological and neurodegenerative disorders, such as Parkinson's and motor neuron diseases (Gravel et al., 1997; Baumgartner and Shine, 1998; Perrelet et al., 2000;

Sakamoto et al., 2003; Azzouz et al., 2004a,b; Zheng et al., 2005; Barkats et al., 2006; Towne et al., 2011). Pseudotyping of a human immunodeficiency virus type 1 (HIV-1)-based lentiviral vector with different types of fusion envelope glycoproteins composed of rabies virus glycoprotein (RVG) and vesicular stomatitis virus glycoprotein (VSVG) segments achieves a high efficiency of retrograde gene transfer in the central and peripheral nervous systems (Kato et al., 2011a,b; Hirano et al., 2013, see Kato et al., 2011c, 2013a for reviews). These pseudotyped vectors are also applicable as a novel strategy for the study of neural circuits underlying a wide range of brain functions by manipulating specific neural pathways in animal models (Kato et al., 2011d, 2013b; Kinoshita et al., 2012; Inoue et al., 2012; Watakabe et al., 2012; Takada et al., 2013; Sooksawate et al., 2013).

The use of fusion glycoprotein type B (FuG-B), which contains the extracellular and 
transmembrane domains of RVG and the cytoplasmic domain of VSVG, generates an HIV-1-based lentiviral vector for highly efficient retrograde gene transfer (HiRet) (Kato et al., 2011a, 2011d). Another fusion glycoprotein type C (FuG-C), which consists of an N-terminal region (439 amino acids) of the extracellular domain of RVG and the membrane-proximal region (16 amino acids) of the extracellular domain and the transmembrane/cytoplasmic domains of VSVG, creates a lentiviral vector for neuron-specific retrograde gene transfer (NeuRet) (Kato et al., 2011b). In addition to displaying a high efficiency of retrograde gene delivery, the HiRet vector transduces neuronal, glial, and neural stem cells around the injection site; whereas the NeuRet vector transduces only neuronal cells around this site (Kato et al., 2011b). Because of the lack of the capability of the NeuRet vector to transduce proliferating cells in brain tissue, this vector system improves the safety of gene therapy trials by reducing the risk of tumorigenesis, which is a significant issue in the case of integrative viral vectors used for gene therapy (Li et al., 2002; Hacein-Bey-Abina et al., 2003; Themis et al., 2005; Beard et al., 2007; Marumoto et al., 2009). In contrast, other combinations of RVG and VSVG segments, including the fusion of the RVG extracellular domain and the VSVG transmembrane/cytoplasmic domains (type A), and that of the N-terminal region of 414 amino acids of RVG extracellular domain and the membrane-proximal region of 41 
amino acids of VSVG extracellular domain and transmembrane/cytoplasmic domains (type D), do not increase the efficiency of retrograde gene transfer (Kato et al., 2011a,b). Although fusion in the membrane-proximal region of viral envelope glycoproteins improves the efficiency of retrograde gene transfer, the part of the junction between RVG/VSVG segments in fusion glycoproteins that confers the most efficacious gene transfer has not yet been determined.

In the present study, we produced various types of fusion glycoproteins, in which the junction between the RVG and VSVG glycoprotein segments diverged in the membrane-proximal region of RVG, and generated HIV-1-based lentiviral vectors pseudotyped with these fusion glycoproteins. We then tested the efficiency of the pseudotyped vectors for the in vivo gene transfer through retrograde transport, comparing that of the NeuRet vector with FuG-C. We found a novel type of fusion glycoprotein, termed type E (FuG-E), that showed improved efficiency of retrograde gene transfer while retaining the property of neuron-specific transduction. This NeuRet vector with FuG-E will provide a powerful tool for genetic treatment of neurological and neurodegenerative diseases and for the study of neural circuit mechanisms underlying various brain functions. 


\section{Materials and Methods}

\subsection{Plasmid Construction}

The envelope plasmid pCAGGS-FuG-C (Kato et al., 2011b) contained FuG-C cDNA under the control of the cytomegalovirus enhancer/chicken $\beta$-actin promoter (Niwa et al., 1991). The domain structures of RVG and VSVG were predicted by a computer algorithm (Rose et al., 1982). The envelope plasmids were constructed that encoded different types of fusion glycoproteins including $\mathrm{RVG}_{1-451} / \mathrm{VSVG}_{459-512}$, $\mathrm{RVG}_{1-445} / \mathrm{VSVG}_{453-512}, \mathrm{RVG}_{1-442} / \mathrm{VSVG}_{450-512}, \mathrm{RVG}_{1-441} / \mathrm{VSVG}_{449-512}$, $\mathrm{RVG}_{1-440} / \mathrm{VSVG}_{448-512}$ (termed FuG-E, see the text for a detailed explanation), $\mathrm{RVG}_{1-437} / \mathrm{VSVG}_{445-512}, \mathrm{RVG}_{1-436} / \mathrm{VSVG}_{444-512}, \mathrm{RVG}_{1-433} / \mathrm{VSVG}_{441-512}$, and $\mathrm{RVG}_{1-430} / \mathrm{VSVG}_{438-512}$. The amino acids were numbered beginning from the $\mathrm{N}$-terminal methionine of RVG or VSVG including the signal peptide sequence. The structure of these fusion glycoproteins are summarized in Fig. 1. For the construction of these plasmids, the DNA fragment containing the N-terminal region of the extracellular domain of RVG was amplified by PCR with the common forward primer and one of the reverse primers 1 to 9 for RVG sequence (see Supplementary Table 1 for the primer sequences), and the fragments containing the membrane-proximal region of the extracellular domain and transmembrane/cytoplasmic domains of VSVG were amplified 
by PCR with one of the forward primers 1 to 9 and the common reverse primer 1 or 2 for the VSVG sequence (see Supplementary Table 1 for the sequences). The DNA fragment encoding each fusion glycoprotein was connected downstream of the cytomegalovirus enhancer/chicken $\beta$-actin promoter of the envelope plasmid by using an In-Fusion Advantage PCR Cloning kit (Clontech, Mountain View, CA). In addition, a part containing the RVG segment in $\mathrm{RVG}_{1-440} / \mathrm{VSVG}_{448-512}$ (FuG-E) cDNA was replaced with the corresponding part derived from the rabies virus Pasteur virus (PV) strain (designated as FuG-E/PV). The nucleotide sequences of the constructed envelope plasmids were confirmed by DNA sequencing analysis.

\subsection{Cell Culture}

HEK293T cells were obtained from the American Type Culture Collection (ATCC No. CRL-11268, Manassas, VA). The cells were cultured in Dulbecco's modified Eagle's medium (Sigma-Aldrich, St. Louis, MO) containing 10\% fetal bovine serum (Invitrogen, Tokyo, Japan), 2 mM glutaMAX supplement (Gibco, Tokyo, Japan), and penicillin-streptomycin of 100 units/ml (Gibco) at $37{ }^{\circ} \mathrm{C}$ with $5 \% \mathrm{CO}_{2}$. 


\subsection{Production of Lentiviral Vectors}

DNA transfection and viral vector preparations were performed as described previously (Hanawa et al., 2002, 2004) with some modifications. The transfer plasmid pCL20c-MSCV-IL-2R $\alpha /$ GFP (Kato et al., 2011d) contained the cDNA encoding human interleukin-2 receptor $\alpha$-subunit (IL-2R $\alpha$ ) fused to enhanced green fluorescent protein (GFP) downstream of the murine stem-cell virus promoter. HEK293T cells were transfected with transfer, envelope, and packaging plasmids by the calcium-phosphate precipitation method. Eighteen hr after transfection, the medium was replaced with fresh medium; and the cells were subsequently incubated for $24 \mathrm{hr}$. The medium was then harvested and filtered through a $0.45-\mu \mathrm{m}$ Millex-HV filter unit (Millipore, Billerica, MA). Viral vector particles were pelleted by centrifugation at $6,000 \times \mathrm{g}$ for $16-18 \mathrm{hr}$ and then resuspended in phosphate-buffered saline (PBS). For injection, vector particles were applied to a Sepharose Q FF ion-exchange column (GE Healthcare, Buckinghamshire, UK) in PBS and eluted with a linear 0.0-1.5 M NaCl gradient. The fractions were monitored at absorbance $260 / 280 \mathrm{~nm}$. The peak fractions containing the particles were collected and concentrated by centrifugation through a Vivaspin filter (Vivascience, Lincoln, UK). 


\subsection{Titration of Lentiviral Vectors}

Viral RNA in the vector stock solution was isolated with a NucleoSpin RNA virus kit (Clontech), and the copy number of the RNA genome was determined by using a Lenti-X qRT-PCR titration kit (Clontech) according to the manufacturer's instructions. Viral RNA was reverse-transcribed at $42^{\circ} \mathrm{C}$ for $20 \mathrm{~min}$, and quantitative PCR was carried out on duplicate samples by using a StepOne real-time PCR system (Applied Biosystems, Tokyo, Japan) under the following conditions: 1 cycle of $95^{\circ} \mathrm{C}$ for $3 \mathrm{~min}$ followed by 40 cycles of $95^{\circ} \mathrm{C}$ for $15 \mathrm{sec}$ and $60^{\circ} \mathrm{C}$ for $30 \mathrm{sec}$. The standard curve was prepared on the basis of serial dilutions of viral RNA control template ranging from $10^{5}$ to $10^{8}$ copies.

\subsection{Intrastriatal Injection}

All the experiments were conducted in accordance with the guidelines of the

National Institutes of Health, and the Ministry of Education, Culture, Sports, Science and Technology of Japan, and were approved by the Animal Research Committee of Fukushima Medical University, Fukushima, Japan. We made all efforts to minimize the number of animals used and their suffering.

Fifty-three C57BL/6J mice (12 weeks old) were used for the present study. Mice 
were anesthetized with sodium pentobarbital $(50 \mathrm{mg} / \mathrm{kg}$, i.p.) and lentiviral vectors were introduced into the dorsal region of the striatum $(1.0 \mu \mathrm{l} / \mathrm{site}, 4$ sites $)$ through a glass microinjection capillary connected to a microinfusion pump. The anteroposterior, mediolateral, and dorsoventral coordinates $(\mathrm{mm})$ from bregma and dura were 1.0/2.0/2.4 (site 1), 1.0/2.0/3.1 (site 2), 0/2.5/2.4 (site 3), and 0/2.5/3.1 (site 4) for the dorsal striatum according to an atlas of the mouse brain (Paxinos and Franklin, 2001) (see Supplementary Fig. 1A).

\subsection{Immunohistochemical Analysis}

Animals were anesthetized with sodium pentobarbital $(50 \mathrm{mg} / \mathrm{kg}$, i.p.) and perfused transcardially with $4 \%$ paraformaldehyde in $0.1 \mathrm{M}$ phosphate buffer ( $\mathrm{pH}$ 7.4). Perfusion was carried out 4 weeks after the injection of the lentiviral vectors. For immunostaining by the avidin-biotin-peroxidase complex method, transverse sections $(30-\mu \mathrm{m}$ thickness) were incubated with rabbit polyclonal antibody for GFP (Molecular Probes, Eugene, OR) at a 1:2,000 dilution, and then with biotinylated donkey anti-rabbit IgG antibody (Vector Laboratories, Burlingame, CA) at a 1:500 dilution. The signals indicating immunoreactivity were visualized with a Vectastain Elite ABC kit (Vector Laboratories). For double-immunofluorescence histochemistry, sections were incubated first with 
rabbit polyclonal anti-GFP antibody (1:2,000 dilution) and then with mouse monoclonal antibodies specific for NeuN (1:400 dilution, Chemicon, Temecula, CA) or glial fibrillary acidic protein (GFAP, 1:400 dilution, Sigma, St. Louis, MO). The sections were then incubated with fluorescein isothiocyanate-conjugated goat anti-rabbit $\operatorname{IgG}$ and Cy3-conjugated goat anti-mouse IgG (1:500 dilution, Jackson ImmunoResearch Laboratories, West Grove, PA). Fluorescent images were taken with a confocal laser-scanning microscope (LSM510, Zeiss, Thornwood, NY) equipped with proper filter cube specifications.

\subsection{Cell Counts}

A series of brain sections were used for immunohistochemistry by the avidin-biotin-peroxidase complex method. The number of immunostained cells in each brain region was counted with a computer-assisted imaging program (NIH Image 1.62, National Institutes of Health, Bethesda, MD). In individual animals, the number of immunostained cells in four sections through the cerebral cortex or thalamic nucleus was counted and the average per section was calculated (see Supplementary Fig. 1B, C for sections used for cell counts). In striatal sections, the number of stained cells in the regions of interest $(0.2 \times 0.2 \mathrm{~mm})$ from four sections was counted; and the percentage of 
NeuN- or GFAP-positive cells was calculated.

\subsection{Statistical Analysis}

All values were expressed as the mean \pm SEM of the data. For statistical comparisons, Student's $t$ test was used with significance set at $p<0.05$.

\section{Results}

\subsection{Improved Retrograde Gene Transfer by Pseudotyping with FuG-E}

To optimize the junction of RVG/VSVG segments in the membrane-proximal region of the glycoprotein extracellular domain for transduction, we initially produced six kinds of fusion glycoproteins, in which the junction of RVG/VSVG segments was shifted every three amino acids in the direction of the $\mathrm{N}$ - or $\mathrm{C}$-terminus on the basis of the junction of FuG-C, including $\mathrm{RVG}_{1-451} / \mathrm{VSVG}_{459-512}, \mathrm{RVG}_{1-445} / \mathrm{VSVG}_{453-512}$, $\mathrm{RVG}_{1-442} / \mathrm{VSVG}_{450-512}, \mathrm{RVG}_{1-436} / \mathrm{VSVG}_{444-512}, \mathrm{RVG}_{1-433} / \mathrm{VSVG}_{441-512}$, and $\mathrm{RVG}_{1-430} / \mathrm{VSVG}_{438-512}$ (see Fig. 1). We generated HIV-1-based lentiviral vectors carrying the IL-2R $\alpha$-GFP as a transgene by pseudotyping with these six fusion glycoproteins, and used the FuG-C-pseudotyped vector as a control. These pseudotyped vectors with an equivalent RNA titer of $2.0 \times 10^{11}$ copies/ml were injected stereotaxically into the 
dorsal striatum of mice (1.0 $\mu \mathrm{l}$ x four sites, see Supplementary Fig. 1A). Sections through the parafascicular thalamic nucleus $(\mathrm{PF})$ were prepared from the injected mice and used for immunohistochemistry with anti-GFP antibody for detection of the transgene expression (Fig. 2A, see Supplementary Fig. 1B for sections used for cell counts). The number of cells immunopositive for GFP appeared to gradually increase along with the shift of the junction in the direction of the $\mathrm{N}$-terminus from $\mathrm{RVG}_{1-451} / \mathrm{VSVG}_{459-512}$ to $\mathrm{FuG}-\mathrm{C}$, and this number appeared to reduce markedly past the junction in FuG-C.

Subsequently, we produced three kinds of fusion glycoproteins, in which the RVG/VSVG segment junction was shifted one or two amino acid(s) in the direction of the $\mathrm{N}$ - or C-terminus from the junction of FuG-C, including $\mathrm{RVG}_{1-441} / \mathrm{VSVG}_{449-512}$, $\mathrm{RVG}_{1-440} / \mathrm{VSVG}_{448-512}$, and $\mathrm{RVG}_{1-437} / \mathrm{VSVG}_{445-512}$ (see Fig. 1). We did not design $\mathrm{RVG}_{1-438} / \mathrm{VSVG}_{446-512}$, because the residue leucine at 439 in $\mathrm{RVG}$ corresponds to the same amino acid residue at 446 in VSVG. We generated HIV-1 lentiviral vectors carrying the IL-2R $\alpha$-GFP transgene by pseudotyping with these three fusion glycoproteins, together with FuG-C. The pseudotyped vectors were injected into the mouse striatum, and PF sections were stained by GFP immunohistochemistry as described above (Fig. 2B). The number of cells immunopositive for GFP in the 
$\mathrm{RVG}_{1-440} / \mathrm{VSVG}_{448-512}$ vector-injected mice was slightly greater than that for the FuG-C vector-injected ones.

To confirm the increased transduction efficiency of the $\mathrm{RVG}_{1-440} / \mathrm{VSVG}_{448-512}$ vector, we again compared the efficiency of retrograde gene transfer into the PF by using just the $\mathrm{RVG}_{1-440} / \mathrm{VSVG}_{448-512}$ and FuG-C vectors (Fig. 2C). The cell number showed a significant difference between the two pseudotyped vectors (Student's $t$ test, $p<0.05$ ), with an approximately 1.2-fold increase in the number of GFP-positive cells in the $\mathrm{RVG}_{1-440} / \mathrm{VSVG}_{448-512}$ vector as compared with the FuG-C-vector. These data indicate that pseudotyping with $\mathrm{RVG}_{1-440} / \mathrm{VSVG}_{448-512}$, which we designated as FuG-E, resulted in the highest efficiency for retrograde gene transfer into the thalamostriatal pathways among the fusion glycoproteins with the junction in the membrane-proximal region.

The gene transfer efficiency of the HiRet vector is improved by the use of a variant of FuG-B, in which the extracellular domain of RVG is replaced by the corresponding part derived from the rabies virus PV strain (Kato et al., 2011d). To test whether this same exchange of RVG segment might improve the efficiency of FuG-E for retrograde gene delivery, we produced a variant of FuG-E, in which the RVG segment was substituted by the corresponding part of the PV strain-derived glycoprotein (FuG-E/PV). The lentiviral vectors pseudotyped with FuG-E and FuG-E/PV were injected into the 
mouse striatum, and PF sections were used for GFP immunohistochemistry (Fig. 3).

The number of GFP-immunopositive cells was indistinguishable between these two pseudotyped vectors, suggesting that the interstrain exchange of RVG sequences did not influence the gene transfer efficiency of the FuG-E vector.

In addition, we tested the efficiency of the FuG-E-pseudotyped vector for retrograde gene transfer into other brain regions. Lentiviral vectors pseudotyped with FuG-E or FuG-C were injected into the mouse striatum, and sections through the primary motor (M1) and somatosensory (S1) cortical areas were stained immunohistochemically for GFP (Fig. 4, see Supplementary Fig. 1C for sections used for cell counts). The number of cells immunopositive for GFP in both the M1 and S1 areas was significantly greater in the FuG-E vector as compared with that in the corresponding areas in the FuG-C vector controls (Student's $t$ test, $p<0.05$ ). These data show that the pseudotyping with FuG-E improved the efficiency of retrograde gene transfer not only into the thalamostriatal pathways but also into the corticostriatal pathways in the brain.

\subsection{FuG-E Pseudotyping Displays the Property of the NeuRet Vector}

The NeuRet vector pseudotyped with FuG-C transduces selectively neuronal cells around the injection site of the vector (Kato et al., 2011b). To examine whether the 
pseudotyping with FuG-E possesses this property of the NeuRet vector, we introduced lentiviral vectors pseudotyped with FuG-E and FuG-C $\left(2.0 \times 10^{11}\right.$ copies/ml) into the dorsal striatum. Sections through the striatum were stained by double-immunofluorescence histochemistry for GFP and the neuronal marker NeuN or for GFP and the astrocytic marker GFAP (Fig. 5). To evaluate the efficiency of gene transfer into neuronal and astrocytic cells in the striatum, we normalized the numbers of $\mathrm{GFP}^{+} / \mathrm{NeuN}^{+}$and $\mathrm{GFP}^{+} / \mathrm{GFAP}^{+}$cells by the total numbers of $\mathrm{NeuN}^{+}$and $\mathrm{GFAP}^{+}$cells, respectively. The ratio of $\mathrm{GFP}^{+} / \mathrm{NeuN}^{+}$relative to the total $\mathrm{NeuN}^{+}$number was $7.5 \pm$ $0.4 \%$ and $7.3 \pm 0.8 \%$ for the FuG-E and FuG-C-pseudotyped vectors, respectively $(\mathrm{n}=$ 4). The ratio of $\mathrm{GFP}^{+} / \mathrm{GFAP}^{+}$cells relative to total $\mathrm{GFAP}^{+}$cell number was $0.6 \pm 0.2 \%$ and $1.0 \pm 0.3 \%$ for the respective FuG-E and FuG-C vectors $(n=4)$. Thus, the FuG-E-pseudotyped vector transduced a small number of neuronal cells and was less capable of transducing glial cells around the injection site, showing the property similar to the NeuRet vector pseudotyped with FuG-C.

\section{Discussion}

In the present study, we aimed at optimizing the junction of RVG/VSVG segments in the membrane-proximal region of the extracellular domain of viral envelope 
glycoproteins for the improvement of the efficiency of retrograde gene transfer by lentiviral vectors. We tested the efficiency of the HIV-1-based vectors pseudotyped with various types of fusion glycoproteins and compared the results with those obtained with the NeuRet vector pseudotyped with FuG-C. As a result, we found a novel type of fusion glycoprotein, which we termed FuG-E, that enabled the lentiviral vector to achieve the highest retrograde gene transfer after intrastriatal injection. This FuG-E-pseudotyped vector transduced selectively neuronal cells around the injection sites, showing the same property of the NeuRet vector.

One amino acid substitution in the protein sequences of FuG-E on the basis of the FuG-C sequences (serine to proline at the residue 440) resulted in the most efficient retrograde gene transfer, although the shift of the RVG/VSVG junction around this substitution generated relatively higher levels of the gene transfer. The mechanism by which the structure of the membrane-proximal region influenced the gene transfer efficiency of the vectors remains to be clarified. Although the membrane-proximal region of VSVG, together with its transmembrane and cytoplasmic domains, mediates the process of fusion of the viral envelope with the cell surface (Robison and Whitt, 2000; Jeetendra et al., 2002), the role of this region in the property of the in vivo gene transfer has not been investigated. RVG is reported to interact with certain neuronal 
receptors, such as the nicotinic acetylcholine receptor $\alpha$-subunit, low-affinity nerve growth factor receptor, and neural cell adhesion molecule (Lentz et al., 1987; Lentz, 1990; Hanham et al., 1993; Gastka et al., 1996; Thoulouze et al., 1998; Tuffereau et al., 1998; see Lafon, 2005 for a review). Changes in the structure of the membrane-proximal region in fusion glycoproteins may influence molecular mechanisms such as the binding of virus to putative receptors and vector entry into nerve terminals. In addition, the viral vector pseudotyped with FuG-E showed little capability to transduce glial cells in the brain, as is the case for the FuG-C pseudotyped vector (Kato et al., 2011b), suggesting that the membrane-proximal region of viral glycoproteins is involved in determining the host range specificity of vector transduction.

The extent of retrograde gene transfer by lentiviral vectors pseudotyped with different types of fusion glycoproteins varies dependent on the neural pathways. For instance, FuG-C pseudotyping, as compared with the HiRet vector pseudotyped with FuG-B, increases the retrograde gene transfer into the corticostriatal pathway, whereas it results in lower transfer efficiency into the thalamostriatal pathway (Kato et al., 2013b). In the present study, FuG-E pseudotyping enhanced the efficiency of retrograde gene transfer into both thalamostriatal and corticostriatal pathways compared with that into 
the corresponding pathways achieved by the FuG-C-pseudotyped vector. On the contrary, the HiRet vector, compared with the FuG-C-pseudotyped one, shows much higher activity to transduce retrogradely motor neurons in the spinal cord and hindbrain after intramuscular injection (Hirano et al., 2013). The retrograde gene transfer into motor neurons by the FuG-E-pseudotyped vector remains to be analyzed in the future.

One of the important issues for gene therapy trials with integrative lentiviral vectors is that the vector insertion into the host genome may lead to tumorigenesis by altering the expression of cellular oncogenes surrounding the integration sites (Li et al., 2002; Hacein-Bey-Abina et al., 2003; Themis et al., 2005; Beard et al., 2007; Marumoto et al., 2009). Neuron-specific gene transfer achieved by the NeuRet vector pseudotyped with FuG-C provides a useful system to reduce the risk of tumorigenesis by suppressing gene delivery into dividing cells such as glial and neural stem/progenitor cells in the brain (Kato et al., 2011b). In this study, we improved the efficiency of retrograde gene transfer of the NeuRet vector by pseudotyping with FuG-E. The use of this new type of NeuRet vector will also be a useful strategy for therapeutic trials of neurological and neurodegenerative disorders, showing the safety of lentiviral vectors by greatly reducing the efficiency of transgene integration into dividing cells.

Another important application of our NeuRet vector system is the study of neural 
circuit mechanisms underlying a variety of brain functions. The system has been already utilized for the selective elimination of neural pathway from brain neural networks in nonhuman primates (Inoue et al., 2012; Takada et al., 2013). The NeuRet vector with FuG-C was used to express the IL-2R $\alpha$-GFP transgene, which is a target molecule of a recombinant immunotoxin, into the corticosubthalamic pathway by injecting the vector into the subthalamic nucleus in macaque monkeys. Then the immunotoxin was injected into the cortical areas, resulting in the selective elimination of the corticosubthalamic pathway from the neural networks. This elimination led to the deletion of early excitatory responses in the output nuclei of the basal ganglia circuit after electric stimulation of the cortical areas, indicating that the corticosubthalamic pathway conveys a specific electrophysiological response to the output nuclei. In addition, the NeuRet vector was applied for the selective and reversible blockade of the neural pathway by expressing tetanus neurotoxin, which blocks synaptic release of neurotransmitters (Sooksawate et al., 2013). The NeuRet vector carrying the tetanus neurotoxin gene under the control of tetracycline responsive element was injected unilaterally into the medial pontine reticular formation in mice, and an adeno-associated vector encoding tetracycline transactivator was injected into the opposite side of the superior colliculus. Doxycycline treatment induced the expression of tetanus neurotoxin unilaterally in the 
crossed tectoreticular pathway. The impaired synaptic transmission led to the visual orienting response, demonstrating a key role of the tectoreticular pathway in the control of visual orienting behaviors. In the present study, we described the improved transduction efficiency of the NeuRet vector by pseudotyping with FuG-E. This new type of the NeuRet vector will further promote the study of the mechanisms of neural networks underlying brain functions, together with the application of the system for gene therapeutic approaches to neurological and neurodegenerative diseases.

\section{Acknowledgements}

This work was supported by a grant-in-aid from Core Research for Evolutional Science and Technology of Japan Science and Technology Agency (Ka. K.) and the Uehara Memorial Foundation (S.K.). We thank St. Jude Children's Research Hospital (Dr. A. Nienhuis) and George Washington University for providing the HIV-1-based vector system. We are grateful to M. Sugawara, M. Kikuchi, N. Sato, M. Watanabe, and T. Kobayashi for their technical support in conducting the animal experiments. 


\section{References}

Azzouz M, Le T, Ralph GS, Walmsley L, Monani UR, Lee DCP, et al.

Lentivector-mediated SMN replacement in a mouse model of spinal muscular atrophy. J Clin Invest 2004a;114:1726-1731.

Azzouz M, Ralph GS, Storkebaum E, Walmsley LE, Mitrophanous KA, Kingsman SM, et al. VEGF delivery with retrogradely transported lentivector prolongs survival in a mouse ALS model. Nature 2004b;429:413-417.

Barkats M, Horellou P, Colin P, Millecamps S, Faucon-Biguet N, Mallet J. 1-Methyl-4-phenylpyridinium neurotoxicity is attenuated by adenoviral gene transfer of human Cu/Zn superoxide dismutase. J Neurosci Res 2006;83:233-242.

Baumgartner BJ, Shine HD. Neuroprotection of spinal motoneurons following targeted transduction with an adenoviral vector carrying the gene for glial cell line-derived neurotrophic factor. Exp Neurol 1998;153:102-112.

Beard BC, Dickerson D, Beebe K, Gooch C, Fletcher J, Okbinoglu T, et al. Comparison of HIV-derived lentiviral and MLV-based gammaretroviral vector integration sites in primate repopulating cells. Mol Ther 2007;15:1356-1365. 
Gastka M, Horvath J, Lentz TL. Rabies virus binding to the nicotinic acetylcholine receptor $\alpha$ subunit demonstrated by virus overlay protein binding assay. J Gen Virol 1996;77:2437-2440.

Gravel C, Götz R, Lorrain A, Sendtner M. Adenoviral gene transfer of ciliary neurotrophic factor and brain-derived neurotrophic factor leads to long-term survival of axotomized motor neurons. Nat Med 1997;3:765-770.

Hacein-Bey-Abina S, von Kalle C, Schmidt M, McCormack MP, Wulffaat N, Leboulch $\mathrm{P}$, et al. LMO2-associated clonal $\mathrm{T}$ cell proliferation in two patients after gene therapy for SCID-X1. Science 2003;302:415-419.

Hanawa H, Hematti P, Keyvanfar K, Metzger ME, Krouse A, Donahue RE, et al. Efficient gene transfer into rhesus repopulating hematopoietic stem cells using a simian immunodeficiency virus-based lentiviral vector system. Blood 2004;103:4062-4069.

Hanawa H, Kelly PF, Nathwani AC, Persons DA, Vandergriff JA, Hargrove P, et al. Comparison of various envelope proteins for their ability to pseudotype lentiviral vectors and transduce primitive hematopoietic cells from human blood. Mol Ther 2002;5:242-251. 
Hanham CA, Zhao F, Tignor GH. Evidence from the anti-idiotypic network that the acetylcholine receptor is a rabies virus receptor. J Virol 1993;67:530-542.

Hirano M, Kato S, Kobayashi K, Okada T, Yaginuma H, Kobayashi K. Highly efficient retrograde gene transfer into motor neurons by lentiviral vector pseudotyped with fusion glycoprotein. PLoS One 2013;8:e75896.

Inoue K, Koketsu D, Kato S, Kobayashi K, Nambu A, Takada M. Immunotoxin-mediated tract targeting in the primate brain: selective elimination of the cortico-subthalamic "hyperdirect” pathway. PLoS One 2012;7:e39149.

Jeetendra E, Robison CS, Albritton LM, Whitt MA. The membrane-proximal domain of vesicular stomatitis virus $G$ protein functions as a membrane fusion potentiator and can induce hemifusion. J Virol 2002;76:12300-12311.

Kato S, Kobayashi K, Inoue K, Kuramochi M, Okada T, Yaginuma H, et al. A lentiviral strategy for highly efficient retrograde gene transfer by pseudotyping with fusion envelope glycoprotein. Hum Gene Ther 2011a;22:197-206.

Kato S, Kobayashi K, Inoue, K, Takada, M, and Kobayashi K. Vectors for highly efficient and neuron-specific retrograde gene transfer for gene therapy of neurological diseases. In: Molina FM, editor. Gene therapy: tools and potential applications. chapter 15. Rijeka: InTech; 2013a. p.387-398. 
Kato S, Kobayashi K, Kobayashi K. Dissecting circuit mechanisms by genetic manipulation of specific neural pathways. Rev Neurosci 2013b;24:1-8.

Kato S, Kuramochi M, Kobayashi K, Fukabori R, Okada K, Uchigashima M, et al. Selective neural pathway targeting reveals key roles of thalamostriatal projection in the control of visual discrimination. J Neurosci 2011d;31:17169-17179.

Kato S, Kuramochi M, Kobayashi K, Inoue K, Takada M, Kobayashi K. Highly efficient retrograde gene transfer for genetic treatment of neurological diseases. In: Xu K, editor. Viral gene therapy. chapter 17. Rijeka: InTech; 2011c. p.371-380.

Kato S, Kuramochi M, Takasumi K, Kobayashi K, Inoue K, Takahara D, et al. Neuron-specific gene transfer through retrograde transport of lentiviral vector pseudotyped with a novel type of fusion envelope glycoprotein. Hum Gene Ther $2011 b ; 22: 1511-1523$.

Kinoshita M, Matsui R, Kato S, Hasegawa T, Kasahara H, Isa K, et al. Genetic dissection of the circuit for hand dexterity in primates. Nature 2012;487:235-238.

Lafon M. Rabies virus receptors. J Neurovirol 2005;11:82-87.

Lentz TL, Hawrot E, Wilson PT. Synthetic peptides corresponding to sequences of snake venom neurotoxins and rabies virus glycoprotein bind to the nicotinic acetylcholine receptor. Proteins 1987;2:298-307. 
Lentz TL. Rabies virus binding to an acetylcholine receptor $\alpha$-subunit peptide. J Mol $\operatorname{Recog} 1990 ; 3: 82-88$.

Li Z, Düllmann J, Schiedlmeier B, Schmidt M, von Kalle C, Meyer J, et al. Murine leukemia induced by retroviral gene marking. Science 2002;296:497.

Marumoto T, Tashiro A, Friedmann-Morvinski D, Scadeng M, Soda Y, Gage FH, et al. Development of a novel mouse glioma model using lentiviral vectors. Nat Med 2009;15:110-116.

Niwa H, Yamamura K, Miyazaki J. Efficient selection for high-expression transfectants with a novel eukaryotic vector. Gene 1991;108:193-199.

Paxinos G, Franklin KBJ. The Mouse Brain in Stereotaxic Coordinates, 2nd ed. San Dirgo: Academic Press; 2001.

Perrelet D, Ferri A, Mackenzie AE, Smith GM, Komeluk RG, Liston P, et al. IAP family proteins delay motoneuron cell death in vivo. Eur J Neurosci 2000;2:2059-2067.

Robison CS, Whitt MA. The membrane-proximal stem region of vesicular stomatitis virus G protein confers efficient virus assembly. J Virol 2000;74:2239-2246.

Rose JK, Doolittle RF, Anilionis A, Curtis PJ, Wunner WH. Homology between the glycoproteins of vesicular stomatitis virus and rabies virus. J Virol 1982;43:361-364. 
Sakamoto T, Kawazoe Y, Shen JS, Takeda Y, Arakawa Y, Ogawa J, et al. Adenoviral gene transfer of GDNF, BDNF and TGF2, but not CNTF, cardiotrophin-1 or IGF1, protects injured adult motoneurons after facial nerve avulsion. J Neurosci Res $2003 ; 72: 54-64$

Sooksawate T, Isa K, Matsui R, Kato S, Kinoshita M, Kobayashi K et al. Viral vector-mediated selective and reversible blockade of the pathway for visual orienting in mice. Front Neural Circuits 2013;7:162.

Takada M, Inoue K, Koketsu K, Kato S, Kobayashi K, Nambu A. Elucidating information processing in primate basal ganglia circuitry: a novel technique for pathway-selective ablation mediated by immunotoxin. Front Neural Circuits $2013 ; 7: 140$.

Themis M, Waddington SN, Schmidt M, von Kalle C, Wang Y, Al-Allaf F, et al. Oncogenesis following delivery of a nonprimate lentiviral gene therapy vector to fetal and neonatal mice. Mol Ther 2005;12:763-771.

Thoulouze MI, Lafage M, Schachner M, Hartmann U, Cremer H, Lafon M. The neural cell adhesion molecule is a receptor for rabies virus. J Virol 1998;72:7181-7190. 
Towne C, Setola V, Schneider BL, Aebischer P. Neuroprotection by gene therapy targeting mutant SOD1 in individual pools of motor neurons does not translate into therapeutic benefits in fALS mice. Mol Ther 2011;19:274-283.

Tuffereau C, Bénéjean J, Blondel D, Kieffer B, Flamand A. Low-affinity nerve-growth factor receptor (P75NTR) can serve as a receptor for rabies virus. EMBO J 1998; 17:7250-7259.

Watakabe A, Kato S, Kobayashi K, Takaji M, Nakagami Y, Sadakane O, et al. Visualization of the cortical projection neurons by retrograde TET-Off lentiviral vector. PLoS One 2012;7:e46157.

Zheng JS, Tang LL, Zheng SS, Zhan RY, Zhou YQ, Goudreau J, et al. Delayed gene therapy of glial cell line-derived neurotrophic factor is efficacious in a rat model of Parkinson's disease. Mol Brain Res 2005;134:155-161. 


\section{Figure legends}

Fig. 1. Structure of viral envelope glycoprotein and amino acid sequences around the junction of RVG/VSVG segments in various types of fusion glycoproteins. Viral envelope glycoprotein consists of extracellular, transmembrane (TM), and cytoplasmic (CP) domains. SP, signal peptide. Amino acid sequences around the RVG/VSVG segment junction in fusion glycoproteins including $\mathrm{RVG}_{1-451} / \mathrm{VSVG}_{459-512}$, $\mathrm{RVG}_{1-445} / \mathrm{VSVG}_{453-512}, \mathrm{RVG}_{1-442} / \mathrm{VSVG}_{450-512}, \mathrm{RVG}_{1-441} / \mathrm{VSVG}_{449-512}$, $\mathrm{RVG}_{1-440} / \mathrm{VSVG}_{448-512}(\mathrm{FuG}-\mathrm{E}), \mathrm{RVG}_{1-437} / \mathrm{VSVG}_{445-512}, \mathrm{RVG}_{1-436} / \mathrm{VSVG}_{444-512}$, $\mathrm{RVG}_{1-433} / \mathrm{VSVG}_{441-512}$, and $\mathrm{RVG}_{1-430} / \mathrm{VSVG}_{438-512}$ are shown. Sequences derived from RVG and VSVG are indicated by blue and red, respectively. Amino acids are numbered beginning from the N-terminal methionine of RVG or VSVG.

Fig. 2. Gene transfer through retrograde transport of HIV-1-based lentiviral vectors pseudotyped with various types of fusion envelope glycoproteins. The pseudotyped vectors encoding the IL-2R $\alpha$-GFP transgene with equivalent RNA titers of $2.0 \times 10^{11}$ copies/ml were injected unilaterally into the dorsal striatum $(1.0 \mu \mathrm{l} / \mathrm{site}$, four sites $)$ of mice. Four weeks later, their brains were processed; and sections through the PF were used for immunohistochemistry with anti-GFP antibody. Representative images of 
transgene expression in the PF are shown. The number of GFP-immunopositive cells in the PF was counted. (A) Retrograde gene transfer by lentiviral vectors pseudotyped with $\mathrm{RVG}_{1-451} / \mathrm{VSVG}_{459-512}, \mathrm{RVG}_{1-445} / \mathrm{VSVG}_{453-512}, \mathrm{RVG}_{1-442} / \mathrm{VSVG}_{450-512}$ $\mathrm{RVG}_{1-436} / \mathrm{VSVG}_{444-512}, \mathrm{RVG}_{1-433} / \mathrm{VSVG}_{441-512}$, and $\mathrm{RVG}_{1-430} / \mathrm{VSVG}_{438-512}$, together with FuG-C as a positive control. An image obtained from the non-injected side is shown as a negative control. $\mathrm{n}=3$ for each group. (B) Gene transfer by lentiviral vectors pseudotyped with $\mathrm{RVG}_{1-441} / \mathrm{VSVG}_{449-512}, \mathrm{RVG}_{1-440} / \mathrm{VSVG}_{448-512}(\mathrm{FuG}-\mathrm{E})$, $\mathrm{RVG}_{1-437} / \mathrm{VSVG}_{445-512}$ or FuG-C. $\mathrm{n}=3$ for each group. (C) Gene delivery of the vectors pseudotyped with $\mathrm{RVG}_{1-440} / \mathrm{VSVG}_{448-512}(\mathrm{FuG}-\mathrm{E})$ or FuG-C. $\mathrm{n}=4$ for each group. ${ }^{*} p<$ 0.05, significant difference from FuG-C-pseudotyped vector (Student's $t$ test). Scale bar: $500 \mu \mathrm{m}(\mathrm{A}-\mathrm{C})$.

Fig. 3. Comparison of retrograde gene transfer between lentiviral vectors pseudotyped with FuG-E and its variant. The lentiviral vectors pseudotyped with FuG-E and FuG-E/PV carrying the IL-2R $\alpha$-GFP transgene $\left(2.0 \times 10^{11}\right.$ copies/ml $)$ were injected unilaterally into the mouse striatum $(1.0 \mu \mathrm{l} / \mathrm{site}$, four sites). Their brains were processed, and sections through the PF were used for GFP immunohistochemistry. Representative images of transgene expression in the PF are shown. The number of immunoreactive 
cells in the PF was counted. $\mathrm{n}=4$ for each group. Scale bar: $500 \mu \mathrm{m}$.

Fig. 4. Retrograde gene delivery into the corticostriatal neurons by a lentiviral vector pseudotyped with FuG-E. The vectors pseudotyped with FuG-E or FuG-C and carrying the IL-2R $\alpha$-GFP transgene $\left(2.0 \times 10^{11}\right.$ copies $\left./ \mathrm{ml}\right)$ were injected unilaterally into the mouse striatum $(1.0 \mu \mathrm{l} / \mathrm{site}$, four sites). The brain was processed, and sections through the M1 and S1 were subjected to GFP immunostaining. Typical images of transgene expression in the M1 and S1 are shown. The number of immunoreactive cells in the $\mathrm{M} 1 / \mathrm{S} 1$ was counted. $\mathrm{n}=4$ for each group. ${ }^{*} p<0.05$, significant difference from FuG-C-pseudotyped vector (Student's $t$ test). Scale bar: $500 \mu \mathrm{m}$.

Fig. 5. Gene transduction around the injection sites by FuG-E-pseudotyped vector. The pseudotyped vectors with FuG-E and FuG-C and encoding the IL-2R $\alpha-$ GFP transgene $\left(2.0 \times 10^{11}\right.$ copies $\left./ \mathrm{ml}\right)$ were injected into the mouse striatum $(1.0 \mu \mathrm{l} / \mathrm{site}$, four sites). Sections through the striatum were stained by double-immunofluorescence histochemistry for GFP and NeuN (A) or for GFP and GFAP (B). Confocal images of GFP and NeuN/GFAP, and their merged images of double immunostaining are indicated. Scale bar: $50 \mu \mathrm{m}(\mathrm{A}, \mathrm{B})$. 
RVG

$\mathrm{RVG}_{1-451} / \mathrm{VSVG}_{459-512}$ $\mathrm{RVG}_{1-445} / \mathrm{VSVG}_{453-512}$ $\mathrm{RVG}_{1-442} / \mathrm{VSVG}_{450-512}$ $\mathrm{RVG}_{1-441} / \mathrm{VSVG}_{449-512}$ $\mathrm{RVG}_{1-440} / \mathrm{VSVG}_{448-512}$ (FuG-E)

FuG-C

$\mathrm{RVG}_{1-437} / \mathrm{VSVG}_{445-512}$ $\mathrm{RVG}_{1-436} / \mathrm{VSVG}_{444-512}$ $\mathrm{RVG}_{1-433} / \mathrm{VSVG}_{441-512}$ $\mathrm{RVG}_{1-430} / \mathrm{VSVG}_{438-512}$ VSVG
${ }_{1}{ }_{1}{ }_{525}$ MVPQV---KEGDEAEDFVEVHLPDVYKQISGGLPNWGK---GETRL

$$
\mathrm{VDL}^{451}
$$

MVPQV---KEGDEAEDFVEVHLPDVYKQISGGWFSSWK---NRLGK $1 \quad 445 / 453$ MVPQV---KEGDEAEDFVEVHLPDVYKQLVEGWFSSWK---NRLGK $11442 / 450$ MVPQV---KEGDEAEDFVEVHLPDVPIELVEGWFSSWK---NRLGK $1 \quad 441 / 449$ MVPQV---KEGDEAEDFVEVHLPDNPIELVEGWFSSWK---NRLGK $1 \quad 440 / 448$ MVPQV---KEGDEAEDFVEVHLPKNPIELVEGWFSSWK---NRLGK $\stackrel{1}{1} \stackrel{439 / 447}{10}{ }^{512}$ 1 437/445 512 MVPQV---KEGDEAEDFVEVGLSKNPIELVEGWFSSWK---NRLGK 1 436/444 512 MVPQV---KEGDEAEDFVETGLSKNPIELVEGWFSSWK---NRLGK $1 \quad 433 / 441$ MVPQV---KEGDEAEDFGDTGLSKNPIELVEGWFSSWK---NRLGK 1 MVPQV---KEGDESLFFGDTGLSKNPIELVEGWFSSWK---NRLGK 1 MKCLL---LPDDESLFFGDTGLSKNPIELVEGWFSSWK---NRLGK 

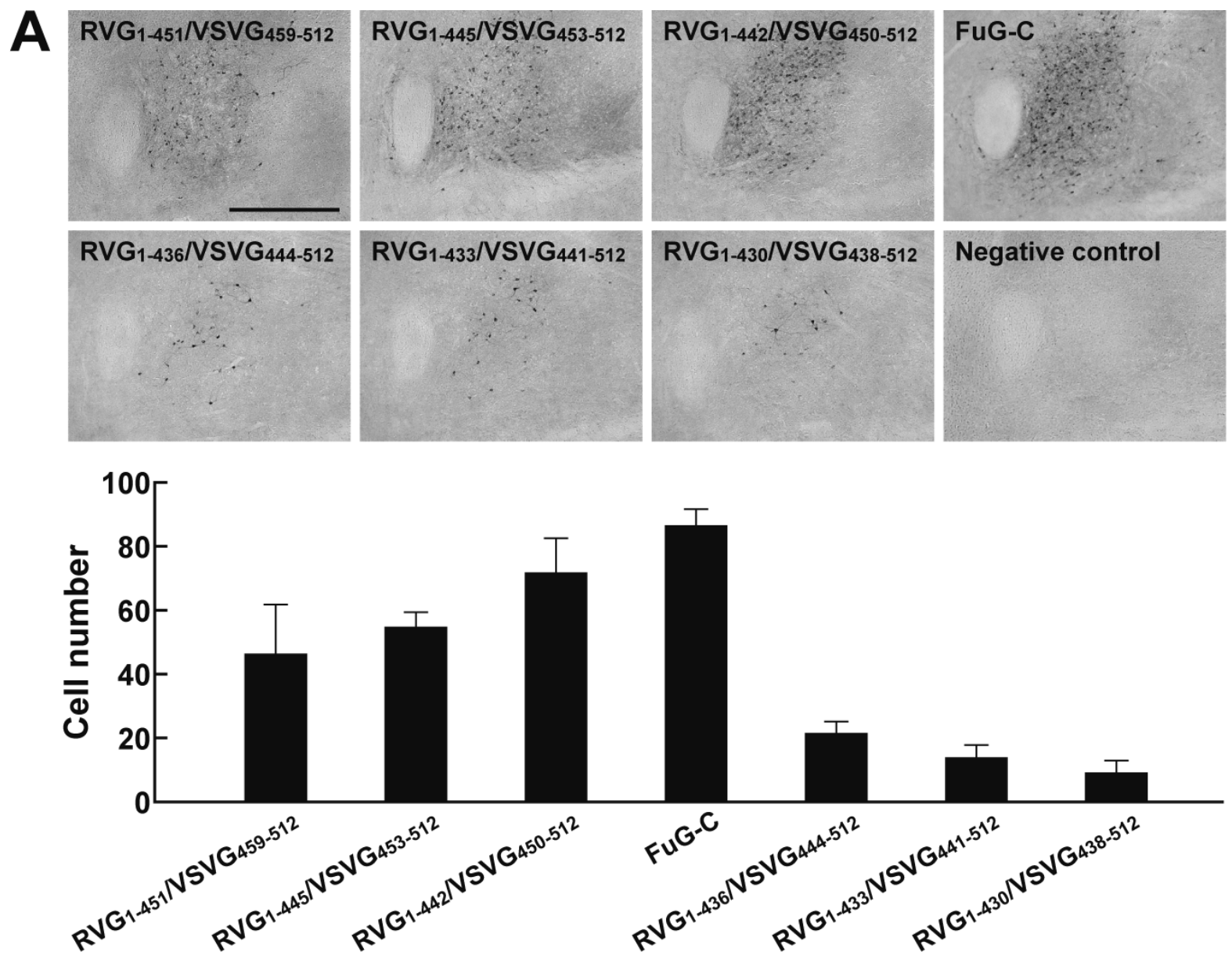
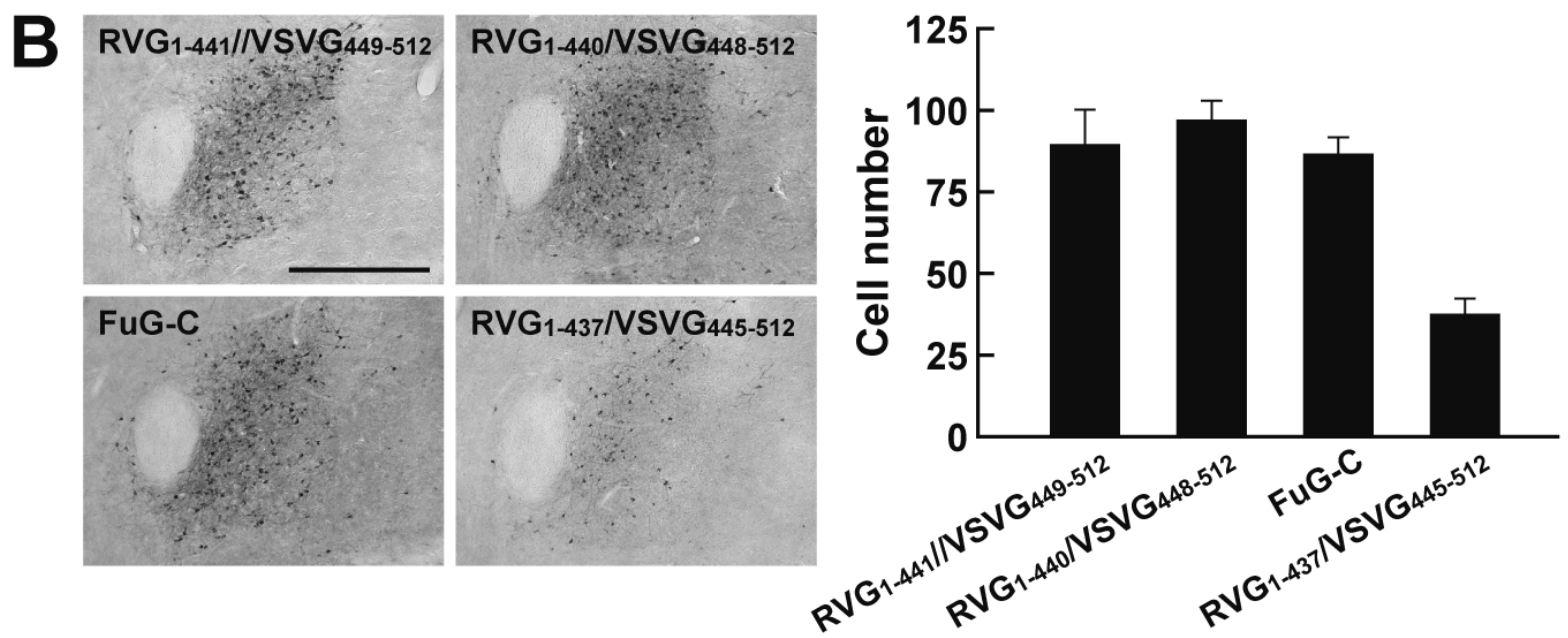

C $\mathrm{RVG}_{1-440} / \mathrm{VSVG} \mathbf{G}_{448-512}$
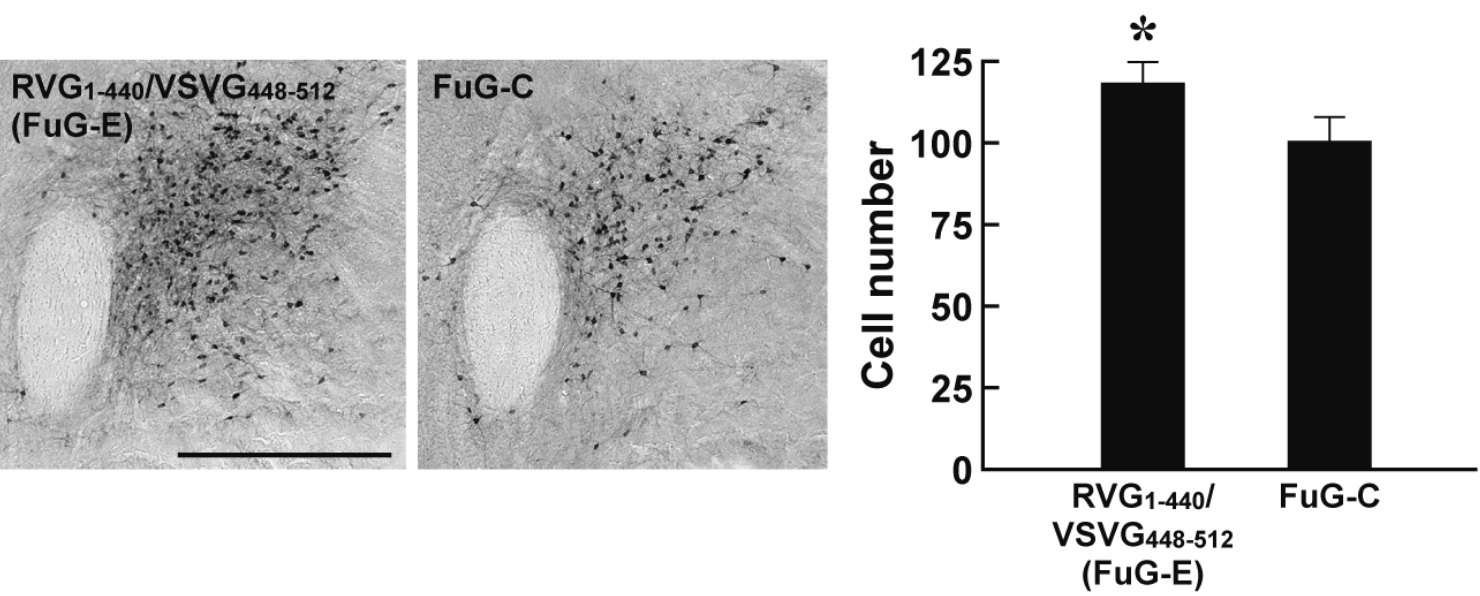
FuG-E

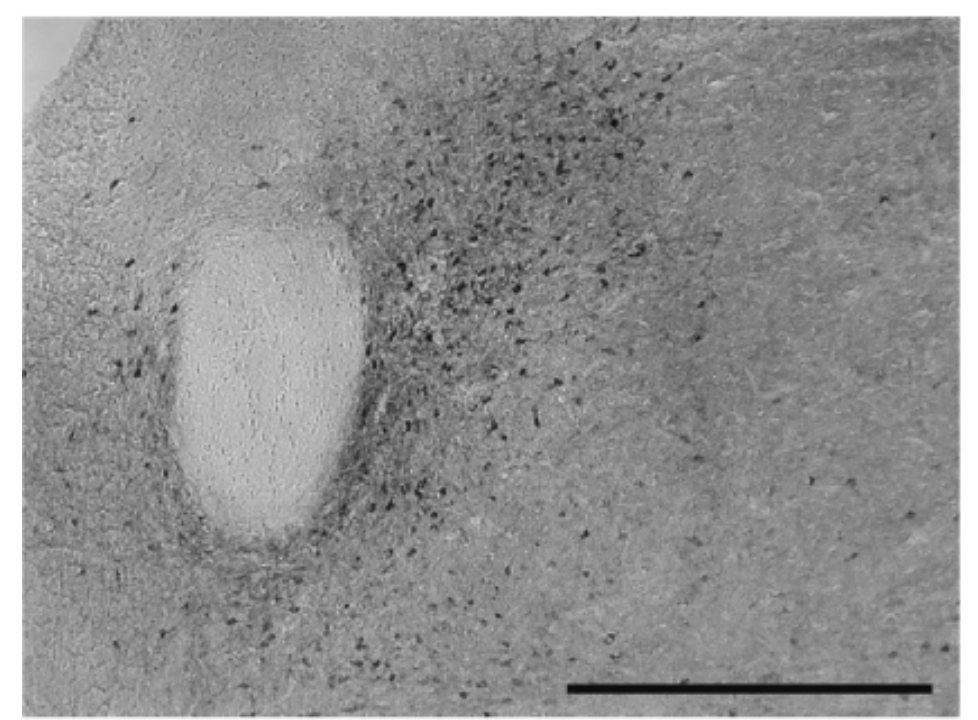

FuG-E/PV

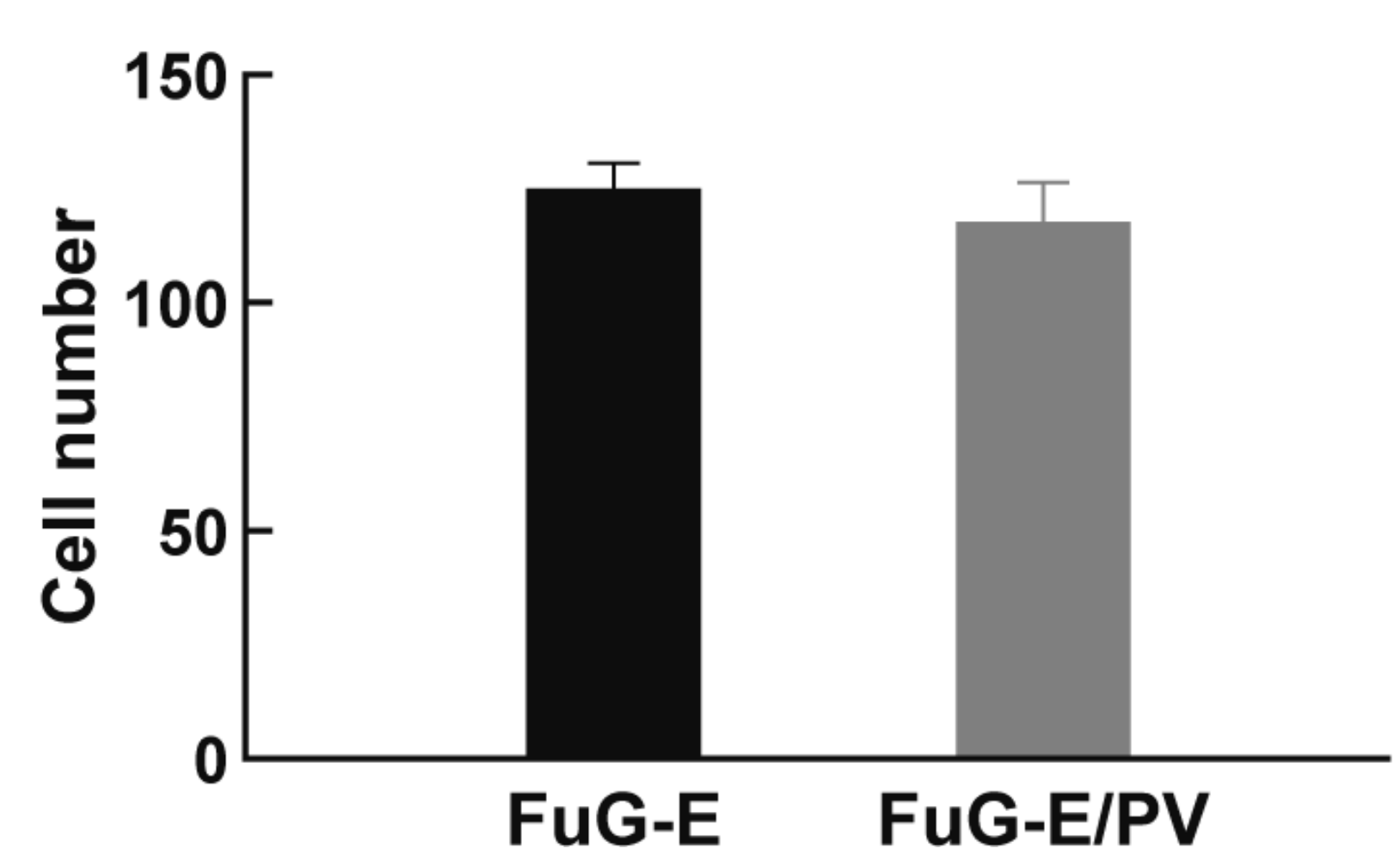

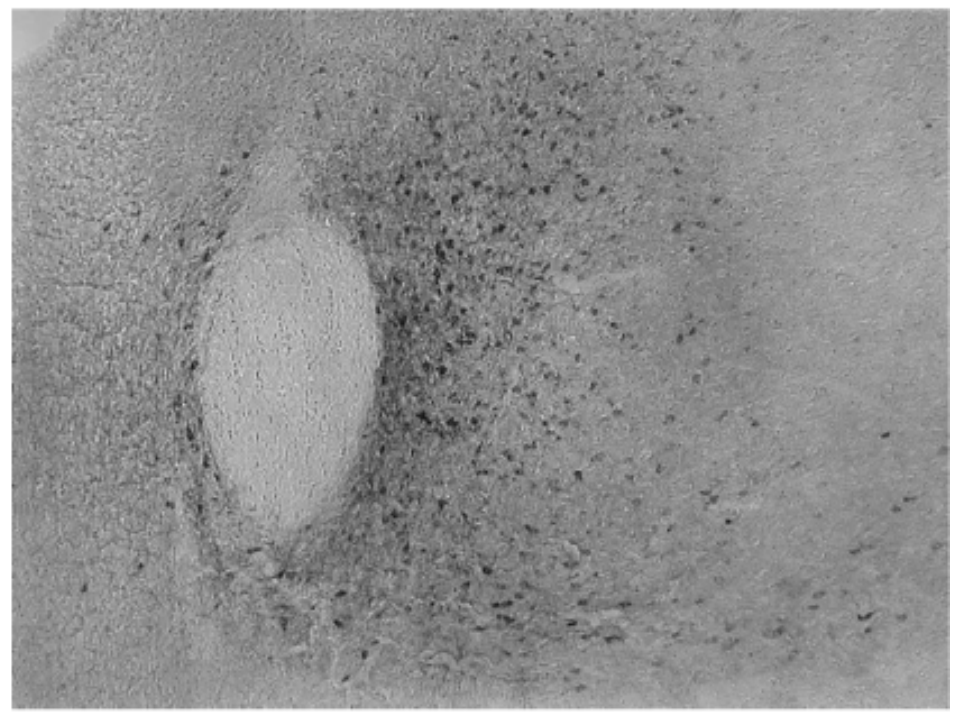


A

\section{M1}
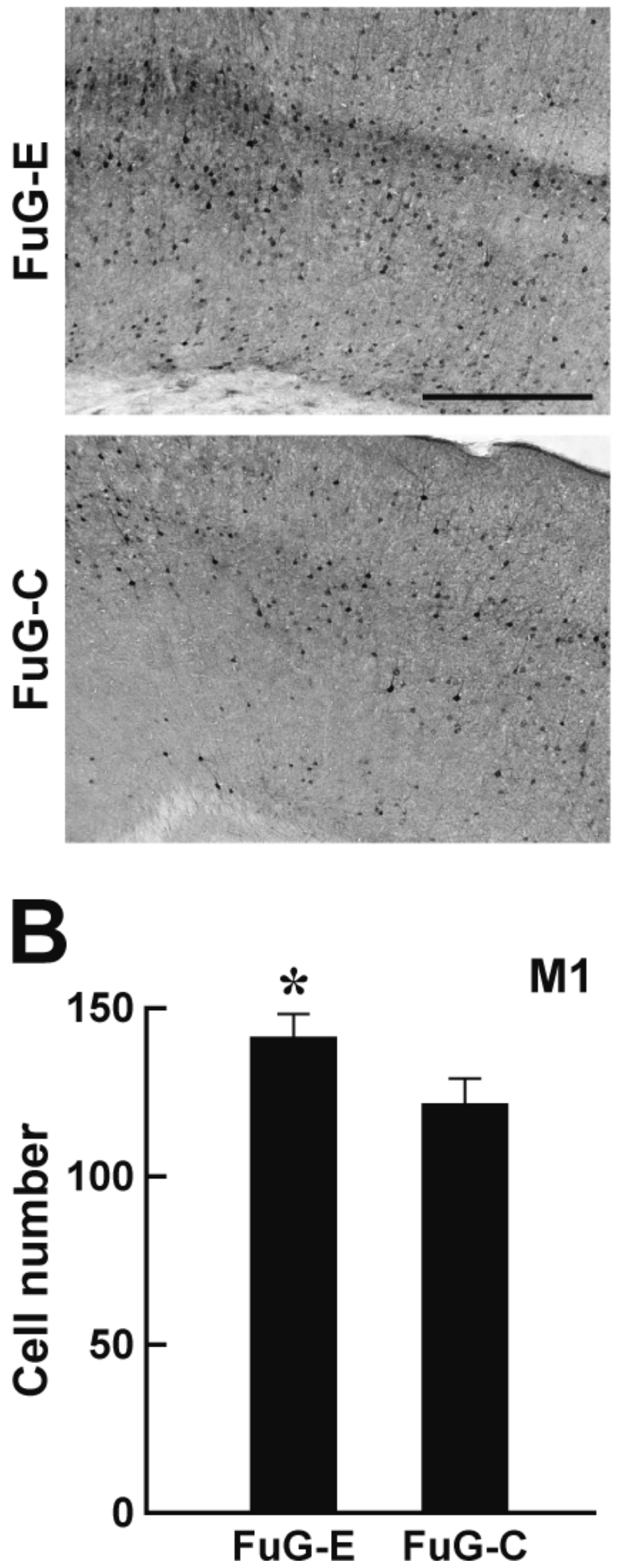

S1
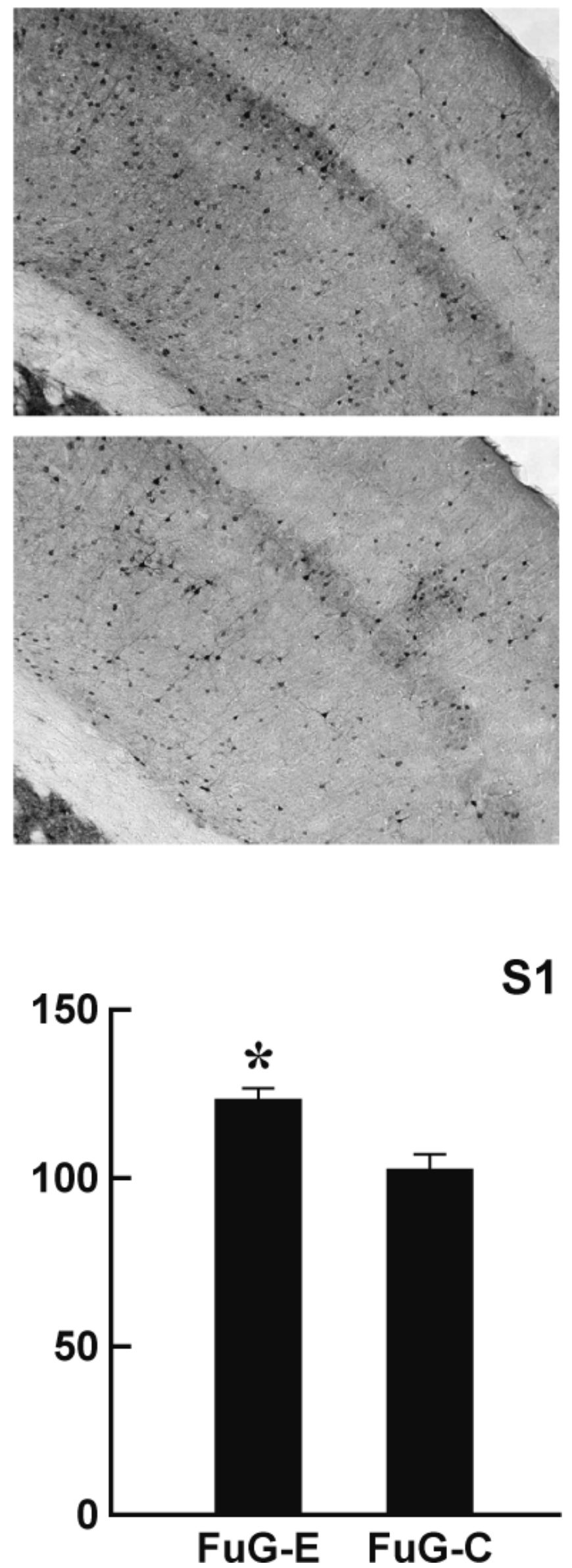

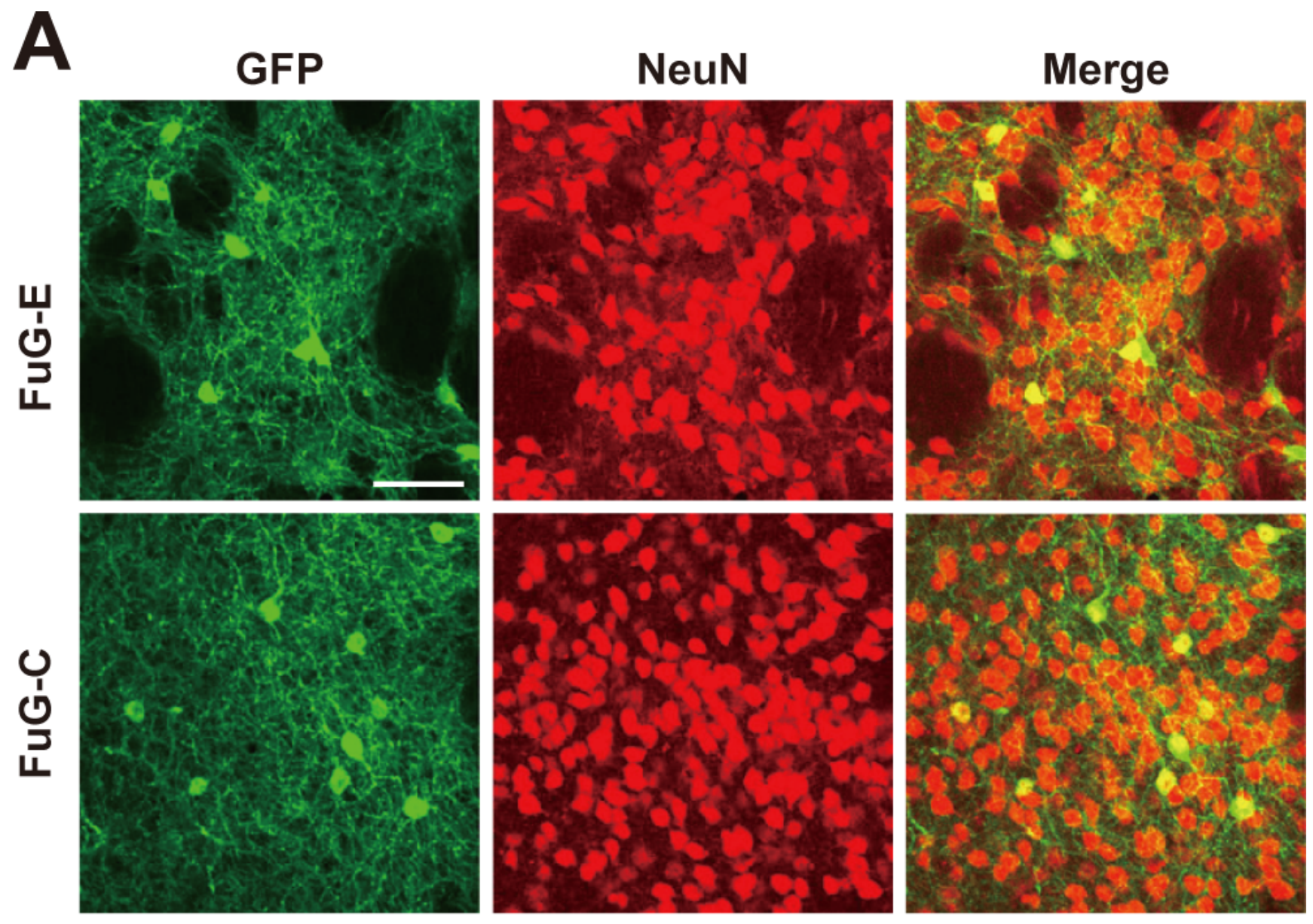

B

GFP
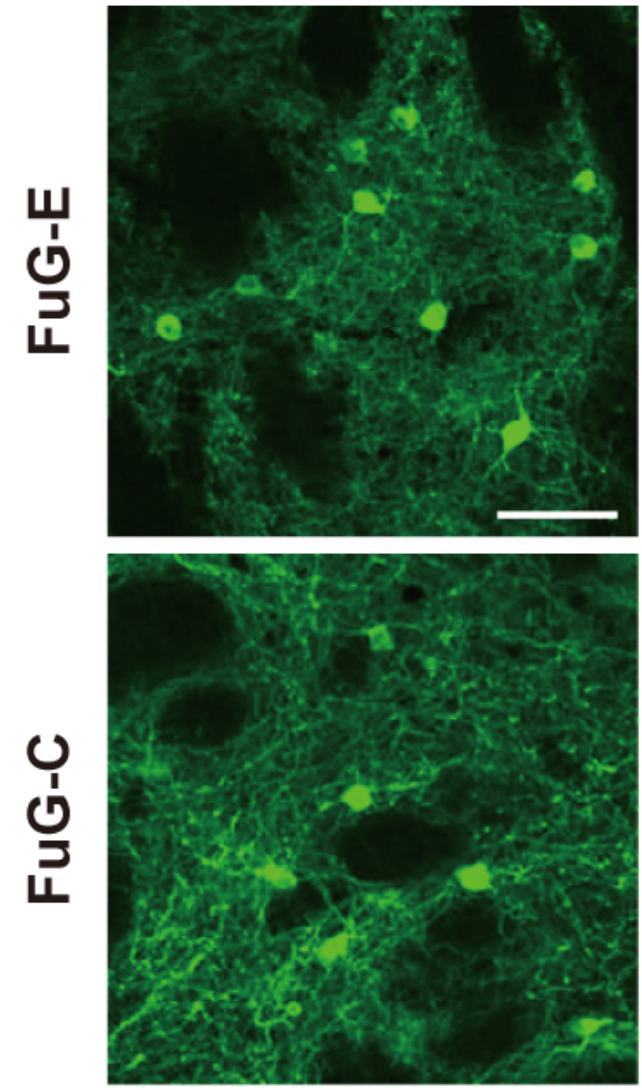

GFAP
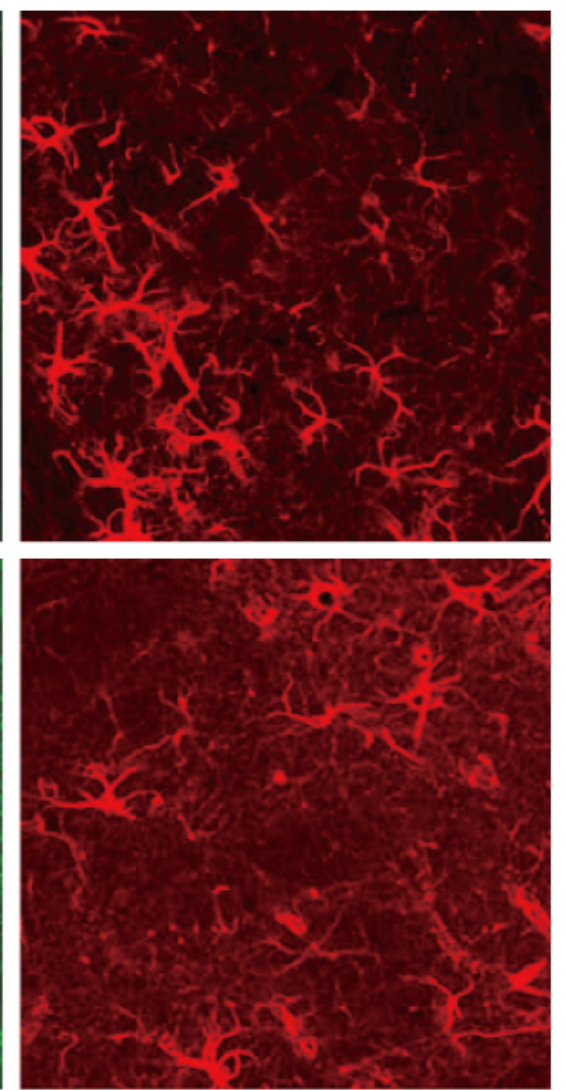

Merge
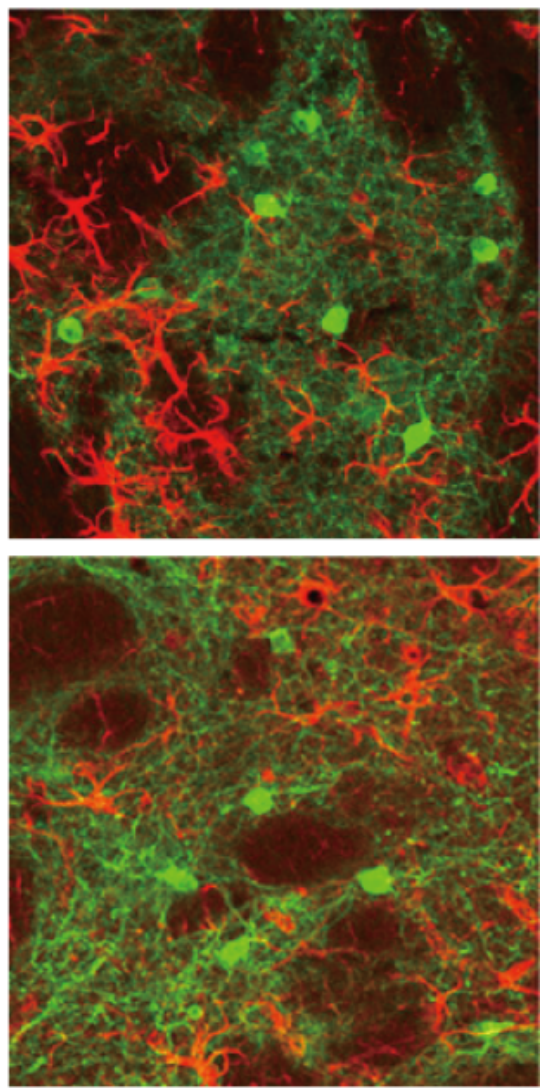


\section{Vectors for Neuron-Specific Retrograde Gene Transfer}

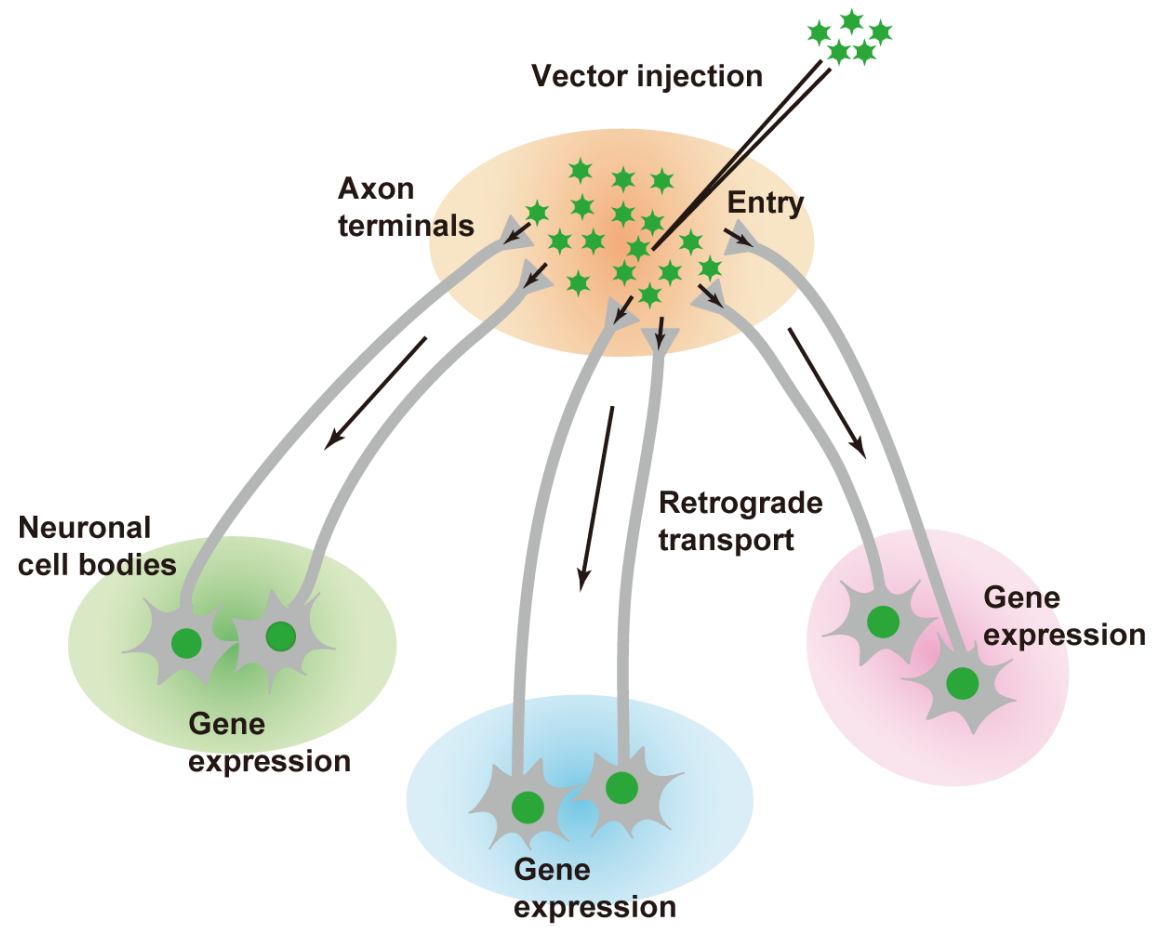

Improvement of Transduction Efficiency by Pseudotyping with FuG-E

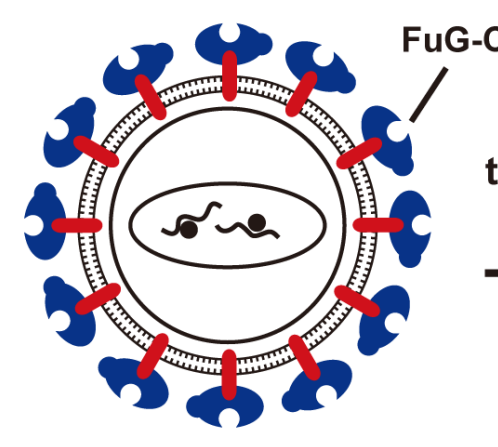

FuG-C

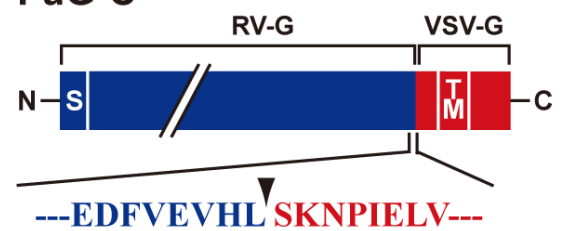

Increased transduction efficiency

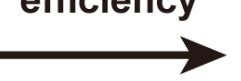

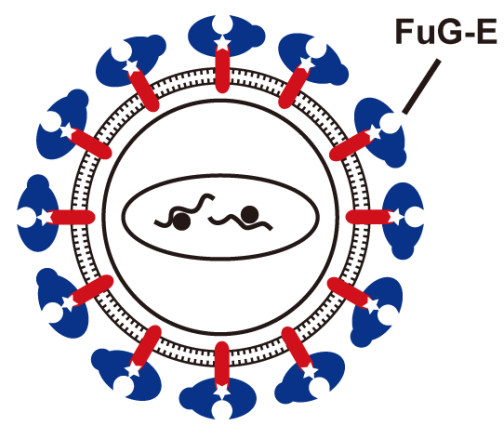

FuG-E

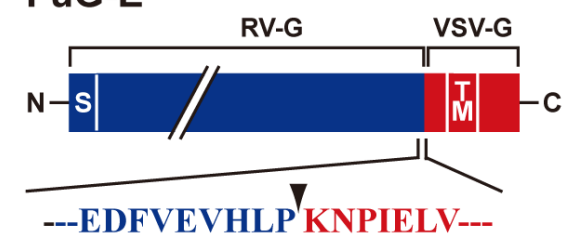

Lentiviral vectors for neuron-specific gene transfer (NeuRet) provide a useful strategy for genetic treatment of neurological diseases and for studying the neural circuit mechanisms underlying various brain functions. In the present study, we improved the efficiency of retrograde gene transfer by pseudotyping the NeuRet vector with a novel type of fusion glycoprotein (FuG-E). 